\title{
Morphological characterization of adolescents tennis players
}

\author{
Roberta Luksevicius Rica',2, João Marcelo de Queiros Miranda², João Henrique Gomes³, Welmo A. Barbosa4, \\ Cleidison M. Santana4, Michel Vetoraci Viana', Francisco Luciano Pontes Junior, Gustavo Allegretti João', \\ Adriano Fortes Maia ${ }^{5}$, Danilo Sales Bocalini ${ }^{5}$
}

\begin{abstract}
Background: The anthropometric profile investigation is considered an important parameter to success in sports, however, there is no available study that investigated biometrics parameters in national level teenage players. In this way the aim of this paper was evaluate the anthropometric characteristics of adolescent tennis players by national level. Methods: The anthropometric and body composition evaluation were recognized on 30 adolescents practicing tennis with at least four years. The following parameters were evaluated: body composition, skin folds, perimeter and fat member. Results: The adolescent tennis players presented eutrophication status according to the mean BMI $\left(\mathrm{kg} / \mathrm{m}^{2}\right)$ and values within normality in relation to the percentage of fat (\%). Conclusion: The results of the present study resembled the findings of literature on the anthropometric characteristics of amateur and professional tennis players.
\end{abstract}

Keywords: Tennis Players; Adolescents; Training; Anthropometry; Physical Fitness.

\section{BACKGROUND}

The Brazilian tennis has reached expressive numbers of practitioners in both leisure practice and high performance. In both scopes, it is necessary that the tennis player acquires a physical condition to support the demands of the modality besides preventing injuries. Tennis is considered a complex modality considering its technical and tactical characteristics; it is intermittent, which intercalates explosive movements of high intensity and short duration with periods of recovery ${ }^{(1)}$. Its practice allows to be carried out in different floors and with different balls, besides, unlike o ther sports, its practice does not have limitation in the duration of the matches with variations from 60 to 300 minutes of duration ${ }^{(1,2)}$.

The anthropometric profile and the body composition may influence the technical and physical performance during tennis game. Some studies ${ }^{(3,4,5,6)}$ have suggested that anthropometric measures can contribute to success in sports. According to ${ }^{(7)}$ the analysis of the anthropometric profile of athletes aims to define an "ideal" morphological condition, specific to each sport, and ${ }^{(8)}$ emphasize that anthropometric evaluation can be considered as an additional strategy for the monitoring and control of training process. In addition, studies ${ }^{(9)}$ consider that knowledge about body composition has as a presupposition to define a specific morphological condition of each sport, presenting the possibility of determining the physical characteristics of athletes who stand out in the early stages of development, as well as being an additional strategy for monitoring and controlling the training process.

There are some studies ${ }^{(9,10,11)}$ available in the literature that have proposed to investigate the anthropometric profile of tennis players, however, to the best of our knowledge, there is no available study that investigated biometrics parameters in national level teenage players. Thus, considering the need for knowledge about the characterization of tennis players, the objective of this study was to evaluate the anthropometric characteristics of adolescent tennis players by national level.

\section{METHODS}

After approval by the Ethics Committee of the Nove de Julho University (138.998) and signing of the informed consent form (TCLE) of the adolescents and their respective responsible, 30 adolescents practicing tennis with at least four years and weekly training volume volunteers participated in this study.

\section{Parameters evaluated}

\section{Anthropometric evaluation}

The height ( $h$ ) was evaluated by Sanny ${ }^{\circledR}$ stadiometer with a precision of $0.1 \mathrm{~cm}$ with the adolescents positioned in Frankfurt plane, barefoot and with the least possible clothing. Body mass (BM) was measured using the same procedures by the Filizola ${ }^{\circledR}$

Corresponding author: Roberta Luksevicius Rica. Rua Ludwik Macal, 130, apto 202. CEP: 29060-030, Jardim da Penha, Vitoria, Espirito Santo, Brasil. Phone: 55-11-995847470. E-mail: robertarica@hotmail.com

1 Universidade São Judas Tadeu, São Paulo, SP, Brasil

Full list of author information is available at the end of the article.

Financial support: Nothing to declare

Submission date 13 September 2018; Acceptance date 23 October 2018; Publication date 03 January 
scale with an accuracy of $0.100 \mathrm{~g}$. The body mass index (BMI) was obtained through the equation: $B M /(H)^{(4)}$.

\section{Body composition}

To estimate body composition, the double indirect method of skin folds was adopted. The triceps and subscapular skin folds were measured by the scientific compass of the Sanny ${ }^{\circledR}$ with precision of $0.1 \mathrm{~mm}$. To estimate the percentage of fat, the equation proposed.

\section{Segmental fat}

The evaluation of segmental fat by dominant arm and leg, the ${ }^{(12)}$ protocol was used to determine the total area of the segments according to equation:

a) $T A A=(A P) 2 / 4 \times \pi$

a) $T L A=(L P) 2 / 4 \times \pi$

being,

TAA $=$ total arm area

$\Pi \mathrm{TA}=$ total thigh area

$\mathrm{AP}=$ arm perimeter

$\mathrm{LP}=$ leg perimeter

The muscularity of the arms and legs was evaluated through the equation suggested by ${ }^{(12)}$ being calculated through the following equations:

a) $\mathrm{AMA}=\mathrm{AP}-(\Pi \times \mathrm{TS}) 2 / 4 \times \pi$

b) $\mathrm{TMA}=\mathrm{TP}-(n \times \mathrm{ThS}) 2 / 4 \times \pi$

being,

$\mathrm{AMA}=$ arm muscle area

TMA $=$ thigh muscle area

$\mathrm{AP}=$ arm perimeter

$\mathrm{TP}=$ thigh perimeter

TS $=$ triceps skinfold

ThS $=$ thigh skinfold

Finally, after performing these equations, the calculation was performed to obtain the segmental fat by subtracting the total area of the muscle area, according to the following equation:.

a) $\mathrm{FA}=$ TAA - AMA

b) $F L=T T A-T M A$

being,

$\mathrm{FA}=$ fat $\mathrm{arm}$

$\mathrm{FL}=$ Fat leg

TAA $=$ total arm area

TTA $=$ total thigh area

$\mathrm{AMA}=$ arm muscle area

TMA = thigh muscle area

\section{Statistical analyses}

The descriptive statistical analysis was evaluated by GraphPrism software, being used as descriptors the mean, standard deviation.
Table 1. Biometric parameters of adolescentes tenistas.

\begin{tabular}{|c|c|c|}
\hline Parameters & Media & DP \\
\hline \multicolumn{3}{|l|}{ Body composition } \\
\hline Body mass (kg) & 69.94 & 2.63 \\
\hline Height (m) & 1.78 & 0.01 \\
\hline $\mathrm{BMI}\left(\mathrm{kg} / \mathrm{m}^{2}\right)$ & 22.01 & 0.95 \\
\hline Fat body (\%) & 16.11 & 1.11 \\
\hline Fat mass (kg) & 11.29 & 1.18 \\
\hline Lean mass $(\mathrm{kg})$ & 58.65 & 1.46 \\
\hline \multicolumn{3}{|l|}{ Skin folds } \\
\hline Triceps (mm) & 9.31 & 1.27 \\
\hline Biceps (mm) & 4.96 & 0.40 \\
\hline Subscapularis (mm) & 8.81 & 0.70 \\
\hline Suprailiac (mm) & 9.24 & 1.49 \\
\hline Thoracic (mm) & 7.45 & 1.18 \\
\hline Abdominal (mm) & 14.01 & 2.56 \\
\hline Suprailiac (mm) & 17.43 & 3.02 \\
\hline Thigh (mm) & 14.75 & 2.61 \\
\hline Sum (mm) & 88.70 & 13.61 \\
\hline \multicolumn{3}{|l|}{ Perimeter } \\
\hline Warm $(\mathrm{cm})$ & 27.89 & 0.91 \\
\hline Thigh (cm) & 53.21 & 2.24 \\
\hline \multicolumn{3}{|l|}{ Fat member } \\
\hline Warm (\%) & 22.45 & 3.29 \\
\hline Thigh (\%) & 15.80 & 2.20 \\
\hline
\end{tabular}

Note: Values expressed in mean \pm standard deviation. BMI: body mass index. IC: interval confidence.

\section{RESULTS}

Table 1 presents the values related to the body composition of adolescents. The adolescent tennis players presented eutrophication status according to the mean BMI $\left(\mathrm{kg} / \mathrm{m}^{2}\right)$ and values within normality in relation to the percentage of fat (\%).

\section{DISCUSSION}

The present study aimed to analyze the data obtained by the evaluation of $\mathrm{BMI}$, body composition and the evaluation of segmental fat in adolescent tennis players. The evaluations of this study found that BMI is in line with what is considered "normal" by the World Health Organization (WHO); low body\% $\mathrm{G}$; and older tennis players have higher arm perimetry value.

The BMI presented a mean of $21.97 \mathrm{~kg} / \mathrm{m} 2$. Understanding that the anthropometric profile can influence performance in sports ${ }^{(5)}$, it is observed that the young of the evaluated in the present had the results were classified as strophic.

Evaluated 20 male tennis players aged over 20 years evaluated the body mass, height and skinfolds analyzed. 
The BMI (24.76 \pm 2.80$)$ parameters were similar to those found in our study.

Although the values of the skinfolds in the present study are different from another study ${ }^{(13)}$, the body fat percentage, studies $^{(14,15)}$ emphasize that body fat (\%)ideas are desirable for a better yield.

Evaluated tennis players participating in the Brazilian Tennis Championship, category 16 years, showed that the percentage of boys fat approached $10.6 \%$ and $20.2 \%$ for girls ${ }^{(16)}$. Similar to our results studies ${ }^{(16,17)}$ presented\% of fats similar to ours. It is known that tennis uses a lot of physical valences related to speed and agility, lower body mass to displace and perform the actual actions of the sport, it is shown to be advantageous to have $\mathrm{a} \% \mathrm{G}$ within the appropriate parameters. In addition, the\% $\mathrm{G}$ values of the present study are in accordance with the amateur and professional players (category sub 18) of the study by ${ }^{(8)}$.

Are expected the upper limbs perimetry parameters presented in this study are in concordance to age and sex. These members, under relaxed or contracted musculature conditions, account for the subcutaneous fat ring, thus, both regional fat and local lean mass may have contributed to the significant differences in their values ${ }^{(18)}$. evaluated 550 tennis players of different ages, sex and categories, and did not find variations in body composition in relation to age groups.

\section{CONCLUSION}

In summary, the results of the present study resembled the findings of other studies ${ }^{(13,14,15,19)}$. literature on the anthropometric characteristics of amateur and professional tennis players. In this way, there seems to be an ideal morphological profile of young athletes practicing tennis, however, success in this modality is associated with other aspects not evaluated in the present investigation, such as physical, technical, tactical and psychological performance.

\section{AUTHOR'S CONTRIBUTION}

$R L R, J M Q M$ and $D S B$ were the main contributors in the study intellectual concept. JHG, WAB, GAJ, CMS and FLPJ contributed in literature review and data analyze. MVM, AFM and DSB had active participation on writing and study preparing.

\section{CONFLICTS OF INTEREST}

Nothing to declare.

\section{AUTHORS DETAILS}

${ }^{2}$ Universidade Cidade de São Paulo, São Paulo, SP, Brasil. ${ }^{3}$ Universidade Federal do Sergipe, São Cristovão, Brasil. ${ }^{4}$ Escola de Artes Ciências e Humanidades da Universidade de São Paulo, São Paulo, Brasil. ${ }^{5}$ Universidade Federal do Espirito Santo, Vitoria, Brasil.

\section{REFERENCES}

1. Fernandez J, Mendez-Villanueva A, Pluim BM. Intensity of tennis match play. Br J Sports Med. 2006;40:387-91.

2. Foss ML, Keteyian SJ. Bases fisiológicas do exercício e do esporte. 6a ed. Rio de Janeiro: Guanabara Koogan, 2000.

3. Barr SI, Mccarger LJ, Crawford SM. Practical use of body composition analysis in sport. Sports Med. 1994;17:277-82.

4. Bayios IA, Bergeles NK, Apostolidis NG, Noutsos KS, Koskolou MD. Anthropometric, body composition and somatotype differences of Greek elite female basketball, volleyball and handball players. J Sports Med Phys Fitness. 2006;46:271-80.

5. Fernandes R, Barbosa T, Vilas-Boas JP. Fatores cineantropométricos determinantes em natação pura desportiva. Rev Bras Cineantropom Des Hum. 2005;7:30-34.

6. Hoare DG. Predicting success in junior elite basketball players: the contribution of anthropometic and physiological attributes. J Sci Med Sport. 2000;3:391-405

7. Ramana YV, Surya MVLK, Sudhakar SR, Balakrishna N. Effect of changes in body composition profile on VO2max and maximal work performance in athletes. JEPonline. 2004;7:34-9

8. Gomes RV, Ribeiro SML, Veibig RF, Aoki MS. Consumo Alimentar e Perfil Antropométrico de Tenistas Amadores e Profissionais. Rev Bras Med Esporte, 2009; 15(6): 436-440.

9. Gomes RV, Ribeiro SML, Veibig RF, Aoki MS. Food intake and anthropometric profile of amateur and professionals tennis players. Rev Bras Med Esporte. 2009; 15(6): 436-440.

10. Cócaro ES, Priore SE, Costa RF, Fisberg M. Food intake and anthropometric profile of adolescent tennis players. J. Brazilian Soc. Food Nutr. 2012; 37(3): 293-308.

11. Lemos EC. Assimetria morfofuncional de jovens tenistas em diferentes estágios de maturação somática. Dissertação de mestrado. Universidade Federal de Santa Catarina. 2015.

12. Rech C, Moura JAR. Antropometria para estimativa da massa muscular. In: Petroski Edio Luiz, Pires-Neto Cândido Simões, Glaner Maria de Fátima. Biométrica. São Paulo: Fantoura, 2010.

13. Sánchez-Muñoz C, Sanz D, Zabala M. Anthropometric characteristics, body composition and somatotype of elite junior tennis players. British J Sport Medicine, 2007; 41: 793-799.

14. Tirapegui, J. Nutrição, metabolismo e suplementação na atividade física. In: Pedrosa RG, Falavign G. (Ed.). Avaliação da composição corporal de atletas. São Paulo: Editora Atheneu, 2005.

15. Cabral CAC, Rosado GP, Silva CHO, Marins JCB. Diagnóstico do estado nutricional dos atletas da Equipe Olímpica Permanente de Levantamento de Peso do Comitê Olímpico Brasileiro (COB). Rev Bras Med Esporte. 2006; 12(6): 345-350.

16. Pereira CF. Perfil corporal de tenistas participantes do campeonato brasileiro de tênis, ambos os sexos, categoria 16 anos: um relato cineantropométrico. Rev. Bras. Treinamento Desportivo, 2001; 6: 53-71.

17. Fernandez J, Mendez-Villanueva A, Pluim BM. Intensity of tennis match play. Br J Sports Med. 2006; 40: 387-391.

18. Salanellas F. Talent Search. Apunts: Educação Física e Desporto (Catalunha), p. 44-45, 2016. http://www.monografias.com/trabajos90/ pruebas-antropometricas-fisiologicas/pruebas-antropometricasfisiologicas2.shtml\#ixzz2ejY28zaY

19. Juzwiak CR, Amancio OM, Vitalle MS, Pinheiro MM, Szejnfeld VL. Body composition and nutritional profile of male adolescent tennis players. J Sports Sci. 2008; 26(11): 1209-1217. 